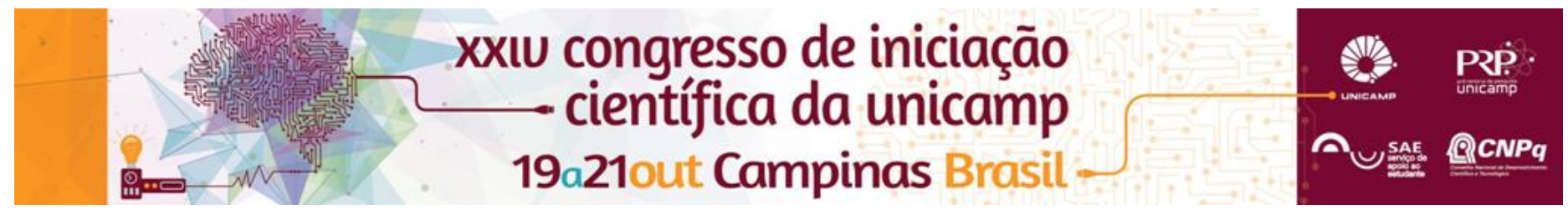

\title{
A DEMOCRACIA DUBETIANA E A FORMAÇÃO SUPERIOR VIA EDUCAÇÃO A DISTÂNCIA
}

\author{
Amanda M. R. Eid ${ }^{\star}$, Ana Elisa Spaolonzi Q. Assis.
}

\section{Resumo}

Desde seu surgimento, no início do século XX, a modalidade de Educação a Distância (EaD), no Brasil, corrobora com concepções de democratização do ensino. Assim, ao se tratar desta temática, inclusive na legislação referente à modalidade, diversas concepções de justiça, igualdade e democratização aparecem e se fundem. Uma dessas concepções é dada por François Dubet, que entende a democratização como sinônimo de igualdade de oportunidades. Com vistas ao fomento desta discussão, e sendo essa concepção de suma importância para que se atinja uma sociedade mais igualitária, este trabalho irá apresentar o projeto de pesquisa de Trabalho de Conclusão de Curso de Pedagogia que problematiza se a democratização dubetiana se faz presente na legislação referente à educação a distância de 1996 a 2007. Para cumpri-lo, serão realizadas leituras de obras pré-selecionadas de Dubet e da legislação; e por meio da análise documental, será feita a comparação entre a democratização descrita pelo autor e a que está presente na legislação nacional da EaD. Como hipótese tem-se que a concepção de democratização enquanto igualdade de oportunidades não está presente, mas sim como igualdade de acesso.

\section{Palavras-chave}

educação a distância, Dubet, democratização.

\section{Introdução}

Dubet (2008) questiona se a igualdade de acesso realmente vem a significar igualdade de oportunidades e justiça. Segundo o autor, a Instituição de Ensino Superior, deve dispor das mesmas oportunidades de êxito a todos os estudantes, independentemente de suas condições sociais. $\mathrm{O}$ autor afirma que essas oportunidades se dariam a fim de se construir uma justa competição, para que assim, cada qual possa assumir o papel na ordem social que seja definido por livre escolha do sujeito e não as custas das circunstâncias sociais, econômicas, etc. Entretanto, ofertar as mesmas oportunidades de sucesso a todos é impossível, ao passo que a instituição de ensino é incapaz de apagar as marcas da desigualdade social que são feitas nos estudantes pela sua condição cultural, histórica e social. Assim a igualdade de acesso se faz bem diferente da igualdade de oportunidades, ou ainda, a igualdade de acesso não garante a igualdade de oportunidades.

Nesta perspectiva, este projeto de pesquisa busca problematizar se a concepção de democratização dubetiana se faz presente na legislação referente à educação a distância de 1996 a 2007.

\section{Resultados e Discussão}

A pesquisa tem caráter qualitativo e como metodologia se utilizará a análise documental. Primeiramente, selecionaram-se as obras de François Dubet a serem lidas e a legislação referente à $\mathrm{EaD}$ indicadas pelo Ministério da Educação (MEC). Ainda, reconheceu-se o histórico da EaD no Brasil por meio do trabalho de Santos (2013) e Moran (2002). Assim, ao serem realizadas as leituras, será feita uma análise com a intenção de problematizar se a concepção de democratização apresentada por Dubet se encontra na legislação brasileira referente à Educação a Distância a partir de 1996 até 2007.

De acordo com Gomes (2009), essa modalidade de ensino abre margens a diversas políticas de ampliação de acesso a cursos de formação superior, especializações e cursos técnicos, tais quais a Universidade Aberta do Brasil (UAB) e o Pró-Licenciatura. Com as várias iniciativas vêse o crescimento da EaD, de acordo com o Censo da Educação Superior de 2013 do Instituto Nacional de Estudos e Pesquisa (INEP) o percentual de crescimento é de 35,3\% considerando-se o período entre 2010 e 2013. Assim sendo, a EaD se torna um importante instrumento de promoção de novas oportunidades de mobilidade social (SANTOS, 2013). Vale questionar que oportunidades seriam essas.

\section{Conclusão}

Dubet, em seu trabalho "Qual democratização do Ensino Superior" (2015), questiona a concepção que considera a democratização apenas como a igualdade de acesso, de oferta de vagas, ou ainda, a democratização como massificação do ensino superior. Essa concepção desconsidera as próprias desigualdades que existem entre os diferentes oferecimentos de cursos de Ensino Superior, como por exemplo, o valor do diploma, do curso e da instituição, que continuam gerando novas desigualdades sociais. O autor afirma então, que a verdadeira democratização exigiria que todas as classes sociais tivessem as mesmas possibilidades de mobilidade social.

A hipótese, então, é a de que essa concepção de democratização como igualdade de oportunidades, não será encontrada nos documentos legais, mas sim como igualdade de acesso, corroborando com os trabalhos de Moran (2002) e Santos (2013) que nos mostram a EaD apenas como igualdade de acesso ao Ensino Superior.

DUBET, F. Democratização escolar e justiça na escola. Revista Educação, Santa Maria/RS, v. 33, n. 3, p. 381-394, 2008.

DUBET, F. Qual Democratização do Ensino Superior? Caderno C R H, Salvador, v. 28, n. 74, p. 255-265, Maio/Ago. 2015.

GOMES, S. G. S. Políticas Públicas em EAD no Brasil. E-Tec Brasil. Tópicos em Educação a Distância. 2009.

INEP/MEC. Resumo Técnico: Censo da Educação Superior 2013. Brasília: Inep, 2013.

MORAN, J. M. O que é Educação a Distância. Universidade de São Paulo. 2002. SANTOS, M. D. M. A Constituição do Campo da Educação Superior no Brasil: 1996-2010. Campinas, SP. [s.n.] 2013. 